\begin{abstract}
Iranica
Abstracta Iranica Revue bibliographique pour le domaine irano-aryen

Volume 34-35-36 | 2017

Comptes rendus des publications de 2011-2013
\end{abstract}

\title{
Khair Yassine. Tell Nimrin. An Archaeological Exploration.
}

\section{Astrid Nunn}

\section{(2) OpenEdition}

1 Journals

\section{Édition électronique}

URL : http://journals.openedition.org/abstractairanica/41565

DOI : 10.4000/abstractairanica.41565

ISSN : 1961-960X

Éditeur :

CNRS (UMR 7528 Mondes iraniens et indiens), Éditions de l'IFRI

\section{Référence électronique}

Astrid Nunn, «Khair Yassine. Tell Nimrin. An Archaeological Exploration. », Abstracta Iranica [En ligne], Volume 34-35-36 | 2017, document 32, mis en ligne le 15 juillet 2016, consulté le 02 octobre 2020. URL : http://journals.openedition.org/abstractairanica/41565; DOI : https://doi.org/10.4000/ abstractairanica.41565

Ce document a été généré automatiquement le 2 octobre 2020.

Tous droits réservés 


\title{
Khair Yassine. Tell Nimrin. An Archaeological Exploration.
}

\author{
Astrid Nunn
}

\section{RÉFÉRENCE}

Khair Yassine. Tell Nimrin. An Archaeological Exploration. Amman, 2011, 248 p.

1 Le Tell Nimrin est situé à $30 \mathrm{~km}$ au sud-ouest d'Amman en Jordanie. Il se trouve exactement à la hauteur de Jéricho à $8 \mathrm{~km}$ du Jourdain. Ce site est resté habité sans discontinuité majeure d'environ $2000 \mathrm{av}$. J.-C. (Bronze Moyen) à aujourd'hui. Même si l'époque perse est peu représentée, deux phases d'occupation sont discernables. La seconde phase semble remonter au IV $\mathrm{s}$. av. J.-C. Une partie semble avoir été détruite par les constructions romaines et byzantines.

\section{AUTEURS}

ASTRID NUNN

Université de Munich 